\title{
Influence of Weather, Wetland Availability, and Mallard Abundance on Productivity of Great Lakes Mallards (Anas platyrhynchos)
}

\author{
Howard V. Singer ${ }^{1,2}$ • David R. Luukkonen ${ }^{3}$ • Llwellyn M. Armstrong ${ }^{2}$. \\ Scott R. Winterstein ${ }^{1}$
}

Received: 12 January 2016 / Accepted: 24 August 2016/Published online: 10 September 2016

(C) The Author(s) 2016. This article is published with open access at Springerlink.com

\begin{abstract}
Waterfowl rely on breeding habitat availability for successful reproduction. Breeding habitat availability likely changes throughout the season and among years as weather patterns change and thus productivity rates are likely susceptible to these changes. We used data from 1961 to 2011 to investigate effects of weather, breeding habitat availability and abundance of breeding mallards (Anas platyrhynchos) on productivity rates of mallards breeding in the Great Lake states (Michigan, Minnesota, and Wisconsin; hereafter GLS). We hypothesized that productivity rates would increase with wetter and warmer conditions however, extreme temperatures may have a negative impact and that high breeding density may negatively impact productivity rates. Specifically, we looked at the effects of average June and July temperature and precipitation, the Palmer Hydrological Drought Index (hereafter PHDI), and wetland counts to model productivity rates across the three states for the time series. We used a reduced time series model set to evaluate the impacts of wetland counts on productivity. We found that in general, wetter conditions, as indexed by high positive PHDI values and relationships with pond abundance, positively affected productivity. We believe that breeding habitat availability is likely a reasonable predictor of mallard productivity rates in the GLS.
\end{abstract}

Howard V. Singer

h_singer@ducks.ca

1 Department of Fisheries and Wildlife, Michigan State University, 480 Wilson Road, East Lansing, MI 48824, USA

2 Present address: Ducks Unlimited Canada, Institute for Wetland and Waterfowl Research, Box 1160, Stonewall Manitoba R0C 2Z0, Canada

3 Michigan Department of Natural Resources, 4166 Legacy Parkway, Lansing, MI 48911, USA
Keywords Mallard · Anas platyrhynchos · GLS · Productivity rate $\cdot$ PHDI

\section{Introduction}

Changing climatic patterns, such as increased drought (Johnson et al. 2005) from hotter and drier conditions, are likely to negatively impact wetland conditions, such as permanency and productivity (Peterson et al. 1997; McCarty 2001; Hoegh-Guldberg and Bruno 2010). Wetlands throughout North America have been lost due to a variety of anthropogenic factors (e.g. loss of habitat due to roads, agricultural expansion, powerline collisions, deforestation; Krapu 1974; Boyd 1985) and environmental factors (Dahl 2011; Prince et al. 1992). Estimates of wetland loss for Michigan are between 50 and $85 \%$, while estimates of loss in Minnesota and Wisconsin are less than $50 \%$ since the 1780's (Dahl and Allord 1996). Furthermore, wetland loss in southern Ontario was $>70 \%$ since-pre-settlement times (c. 1800; Snell 1987). Climate prediction models for the Mid-west suggest summer temperatures and precipitation will likely increase and decrease respectively, thus exacerbating future rates of wetland loss.

An important function of wetlands is as wildlife habitat and breeding waterfowl depend on wetlands for successful reproduction (Krapu and Reinecke 1992; Anteau 2012) as wetlands provide food resources for breeding, provide concealment from predators, and function as brood rearing habitat. It is well documented that the Prairie Pothole region (hereafter PPR) is an important area for breeding waterfowl and the wet-dry cycles of wetlands in this region are important in maintaining productivity (Boyd 1981; Krapu et al. 1983; Reynolds 1987). Unlike the PPR, wetlands of the Great Lake States (Michigan, Minnesota, and Wisconsin; hereafter GLS) are more 
permanent and sometimes considered less productive for dabbling ducks than those of the PPR (Reynolds 1987; Kantrud et al. 1989; Euliss et al. 2004; Johnson et al. 2004; Simpson et al. 2005; Soulliere et al. 2007), although there is uncertainty about how productivity of dabbling ducks breeding in the GLS varies with weather and wetland hydrology (but see Hoekman et al. 2004).

A substantial loss of wetlands could cause a reduction in breeding habitat availability and quality and subsequently duck population declines (Larson 1994; Glick 2005). Annual variation in duck populations have been highly correlated with wetland abundance indices during the breeding season (Crissey 1969, Canadian PPR; Leitch and Kaminski 1985, Sasketchawan; Johnson and Shaffer 1987, US and Canada PPR; Kaminski and Gluesing 1987, Mississippi flyway and Canada Prairie-Parklands; Reynolds 1987; Batt et al. 1989, PPR; Bethke and Nudds 1995, Canadian Prairie-Parklands; Krapu et al. 1997, United States PPR). Furthermore, Heitmeyer and Fredrickson (1981) concluded that mallard recruitment may also be influenced by wetland conditions on the wintering grounds, however Kaminski and Gluesing (1987) found breeding ground habitat conditions more heavily influenced recruitment rates; thus mallard recruitment and subsequently population size may respond to wetland levels throughout the annual cycle. Furthermore, other factors may also contribute to variation in per capita female mallard production of young contributing to fall populations (hereafter productivity rates).

Productivity rates of breeding female dabbling ducks are thought to be primarily influenced by predation, but environmental factors and contaminants can also decrease duckling survival (Talent et al. 1983; Ringleman 1992; Henny et al. 2000). Cold and wet weather following hatching is known to decrease duckling survival, potentially influencing productivity (Korschgen et al. 1996; Cox et al. 1998; Krapu et al. 2000; Pietz et al. 2003). Waterfowl require high quality food resources and brooding cover for successful reproduction (Sedinger 1992; Cox et al. 1998) which can be provided by suitable wetlands. Wetlands with open water and flooded emergent vegetation that produce invertebrate foods are important for duckling survival (Weller and Spatcher 1965; Bloom et al. 2012). Such wetlands are found throughout the GLS. Wetlands throughout the GLS have been invaded by a myriad of invasive species (i.e. Purple loosestrife, (Lythrum salicaria); Phragmites (Phragmites australis); Eurasian Watermilfoil (Myriophyllum spicatum) over the past 30 years (Welling and Becker 1993). The ecological impact from aquatic invasive species is not well understood (Parker et al. 1999), but invasive species may displace native species in wetlands, thus reducing breeding habitat available to waterfowl (Thompson et al. 1987) and potentially displacing breeding ducks. Furthermore, displacement of breeding ducks into inferior quality breeding habitats could lead to variation in productivity through density dependent factors.

This research assesses annual variation of mallard productivity rates in the GLS and factors affecting productivity rates of mallards breeding in the GLS. We estimated annual productivity rates of mallards breeding in the GLS to understand how productivity changed over the period 1961-2011 and was affected by wetland habitat conditions (i.e., via variation in regional hydrology), weather, and mallard abundance during the breeding season. Here, we define productivity rate as the ratio of young to adult females from the autumn hunting season (fall age-ratios) within each GLS. We hypothesize that productivity rates would be positively related to indices of breeding habitat availability, temperature, and precipitation during the breeding season and that density dependence on the breeding grounds would lead to lower productivity rates when breeding abundance was high in relation to wetland abundance (Kaminski and Gluesing 1987). Understanding the link, if one exists, between productivity rates and weather patterns may help managers focus habitat management goals at particular times of the breeding season or on wetlands that provide habitat at critical periods of the reproductive process. Furthermore, with the uncertainty of future weather patterns, managers may have to scale back population goals based on breeding abundance increases or declines under varying habitat conditions.

\section{Study Area and Methodology}

This study included mallards breeding in the GLS, which are managed as part of the mid-continental population of mallards (U. S. Fish and Wildlife Service 2013). Roughly $80 \%$ of the GLS lies within the Prairie Hardwood and Boreal Hardwood Transition ecoregions except for parts of western and southern Minnesota and a small portion of southeastern Michigan and western and southern Wisconsin, which are considered Prairie Pothole and Eastern-Tallgrass Prairie ecoregions respectively (NABCI 2000). Weather patterns in this region are largely driven by extreme snow events caused by cold air masses moving over warmer water bodies (Scott and Huff 1996) and wetlands are more permanent than those of the PPR. Mallards in this region contributed only $8-15 \%$ to the entire mid-continent mallard population (U. S. Fish and Wildlife Service 2013) which is what managers use to determine harvest regulations. Harvest regulations reflect more strongly changes in the core PPR breeding grounds populations, which could lead to more liberalized or conservative harvest regulations in the GLS regardless of GLS mallard population fluctuations under the current harvest management system.

To estimate fall age ratios, we used samples of mallards harvested in the GLS and collected as part of the United States Fish and Wildlife Service (USFWS) Parts Collection 
Survey (wing-bees) from 1961 to 2011. Estimates of harvest by age/sex cohorts were derived from data collected during Mississippi Flyway "wing bees" and provided by USFWS Harvest Surveys Section personnel; we restricted the analyses to birds taken during September 1-October 31 as these months represent a period when harvest should be largely comprised of local breeding birds as large scale migrations of mallards from other breeding areas have not begun into the Great Lakes region (Jessen 1970; Krementz et al. 2013). Also, mallard harvest derivations for Michigan and Wisconsin, 1995-2009, suggest mallard harvest largely comes from local (within state) breeding mallards (68\% and $73 \%$ respectively), however mallard harvest in Minnesota is comprised of roughly half (51\%) local breeding mallards (T. Arnold and C. de Sobrino (unpub data)). Zuwerink 2001, found $>50 \%$ of mallard harvest was derived from local breeding birds for Michigan and Wisconsin, 1990-1997.

Our methods for estimating productivity are derived from ratios of cohort-specific abundances estimated via modified Lincoln-Petersen estimators (Lincoln 1930). First, we estimated direct recovery rates for each state/age class (DRR) defined as, the proportion of the banded sample that was shot, retrieved, and reported (Shot) during the hunting season immediately following banding, $D R R_{i j k}=\frac{\text { Shot }_{i j k}}{\text { Band }_{i j k}}$; where Band $_{i j k}$ is the number of banded mallards in year ${ }_{\mathrm{i}}$, age class ${ }_{\mathrm{j}}$ of sex $\mathrm{k}_{\mathrm{k}}$. We then adjusted DRR estimates for reporting rates to estimate harvest rate $(\mathrm{HR})$ by the equation, $H R_{i}=\frac{D R R_{i}}{R R_{i}}$; where $R R_{i}$ is the annual reporting rate as estimated from reward band studies (Nichols et al. 1991). We adopted 2 different reporting rates used by others analyzing GLS mallard recoveries (T. Arnold, unpub data; $38 \%$ for 1961-1995 and $77 \%$ for 1996-2011). Band reporting rates increased beginning about 1996 when implementation of "toll-free" bands was adopted, allowing hunters to report harvested birds via telephone where previously birds could only be reported via USPS mail service (Royle and Garretson 2005). We estimated cohort specific fall abundance as, $N_{i j}=\frac{H_{i j}}{H R_{i j}}$, where $H_{i j}$ is the harvest of year ${ }_{\mathrm{i}}$ and cohort $_{\mathrm{j}}$ estimated from the parts collection survey data and $H R_{i j}$ is the harvest rate of cohort ${ }_{\mathrm{j}}$ in year ${ }_{\mathrm{I}}$ (March and Hunt 1978; Reynolds 1987; Zimmerman et al. 2010). Finally, to estimate productivity rates, we used $P R=\frac{N_{j f+} N_{j m}}{N_{a f}}$, where $N_{j f+}$ $N_{j m}$ is the estimate of juvenile female and male abundance, respectively divided by the estimate of adult female abundance. Sample size of band recoveries in some year/states was small, so we used a 5-yr. moving average of direct recovery rates to adjust fall age ratios (Zimmerman et al. 2010).

We used the Mixed Models Procedure (PROC MIXED) in SAS (SAS Institute Inc 2004) to model annual response of productivity rates to temperature, precipitation, wetland hydrological conditions, and mallard abundance. We excluded one and two years of data from WI and MI respectively as productivity estimates were extreme outliers (SAS Institute Inc 2004). We used Palmer Hydrological Drought Indices (hereafter PHDI; NCDC 2012) or wetland abundance estimates from state specific spring aerial waterfowl surveys (BPOP surveys; hereafter POND) as measures of breeding habitat availability. The PHDI is a long-term drought index used to reflect reservoir levels and ground water conditions (NCDC 2012); positive PHDI values relate to wetter than average periods. POND estimates were not available for the entire 1961-2011 time series because state waterfowl surveys began at different periods (MI 1992, MN 1968, and WI 1973). We tested for the effects of precipitation and temperature on productivity rates by including average June and July temperature (hereafter JUNET and JULYT respectively) and average June and July precipitation (hereafter JUNEP and JULYP respectively) from each state. These weather variables represent a time period post-hatch, when duckling survival is quite variable, thus potentially influencing productivity rates. Density dependence in productivity is one of the current parameters used to evaluate mallard population dynamics under the Adaptive Harvest Management protocol (U. S. Fish and Wildlife Service 2014). To test for the effects of density dependence, we included state specific annual mallard abundance estimates (hereafter MALL). The POND variable provided a metric to assess available breeding habitat availability which is thought to be a limiting factor to reproduction (U. S. Fish and Wildlife Service 2014); however, since POND was not available across the 51-year study and both MN and WI do not survey the entire state, we assessed a second model set using a 3-month average (April-June) PHDI to index breeding habitat conditions during peak settling and nesting (Bellrose 1976). To evaluate potential time lag effects, we considered a one-year lag effect of PHDI and POND (PHDI_LAG and POND_LAG, respectively). All predictor variables were continuous and standardized with a mean of zero and standard deviation of one.

The global model for the first set of candidate models (hereafter PHDI models) included the variables: PHDI, PHDI_LAG, JUNET, JULYT, JUNEP and JULYP. State was specified by the use of two dummy variables, ST_MI (equal to 1 if state $=$ Michigan and 0 otherwise) and ST_MN (equal to 1 if state $=$ Minnesota and 0 otherwise). All one-way interactions with $\mathrm{ST}_{-}$and weather variables (i.e. ST_MN*JUNEP) were also included. Likewise, the global model for the second set of candidate models (hereafter POND models) excluded PHDI and PHDI_LAG, but included all precipitation and temperature variables in addition to POND, POND_LAG, and MALL.

We compared models using Akaike's information criterion corrected for small sample size $\left(\mathrm{AIC}_{\mathrm{c}}\right.$; Burnham and Anderson 2002) by using a backward selection modelling approach by removing variables while maintaining model hierarchy. Variables were removed from a model based on the ratio of the effect estimate to standard error until only an intercept term remained. Since we were interested in model 
prediction, we model-averaged parameter estimates from models within $4 \mathrm{AIC}_{\mathrm{c}}$ of the top ranking model in the PHDI model set. However for the POND data set, main effect model-averaged estimates were only based on models without corresponding interactions with the $\mathrm{ST}_{-}$dummy variables (Grueber et al. 2011). Also, we externally validated our models by withholding $33 \%(n=17)$ of the data in the PHDI model set. We did not withhold data for the POND data set as the number of observations was insufficient. We then assessed model fit by fitting a linear regression model to the actual and predicted responses on the test data sets from the best fitting model and examined $r^{2}$.

\section{Results}

\section{Productivity Rate Estimates}

Mean mallard productivity rates, 1961-2011, were 2.9, 2.8, and 3.1 young/adult hen for MI, MN and WI respectively (95\% CI: $\pm 0.35, \pm 0.27$, and \pm 0.48 young/adult hen; Fig. 1 ). Productivity rates varied annually and ranged from 1.3-7.7, 0.7-4.0, and 1.0-9.8 young/adult hen for MI, MN, and WI, respectively (Fig. 2). Pearson correlation results suggest slight positive correlation between Minnesota and Wisconsin productivity rates (Table 1).

\section{PHDI Model Results}

All interactions between state and weather related variables were not retained in the final model. The best fitting model included the main effects of ST_MN and PHDI (Table 2).

Beta terms from the top model suggest that Minnesota productivity rates are different than those of Wisconsin (Fig. 3); WI has greater productivity but effects of weather and PHDI are similar across states. PHDI was positively related to productivity rates and was the most influential weather related predictor variable explaining variation in productivity rates. JULYT was positively related to productivity rates whereas JUNET was negatively related to productivity rates. All other variables examined including interactions with ST were removed from the final model through backwards selection process. External validation results suggest that the top ranking

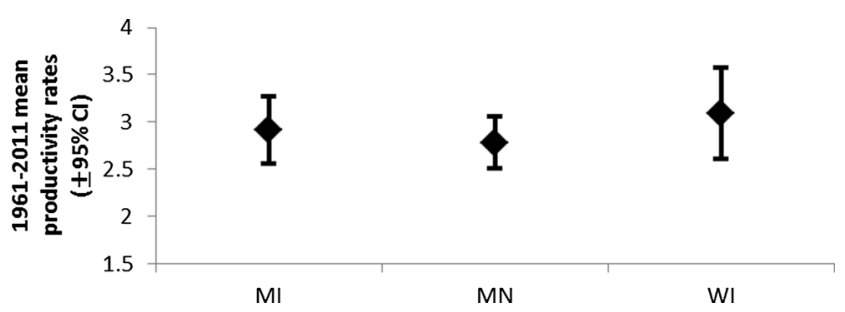

Fig. 1 Mean productivity rates for mallards in the 3 GLS $( \pm 95 \%$ CI) 1961-2011 model explained $<0.1\left(\mathrm{r}^{2}=0.07\right)$ of the variation in productivity rates.

\section{POND Model Results}

Results were similar to that of the previous model set in that productivity rates were lower for Michigan and Minnesota than they were Wisconsin (Fig. 4). The effect of POND showed strong positive correlation with productivity in Minnesota but was weakly negatively correlated with productivity in Michigan and Wisconsin. Also, JUNET and JULYT had similar effects as the previous model set in that JUNET was negatively associated with productivity and JULYT was positively associated with productivity except that effects of JULYT varied by state and there was a stronger effect of JULYT in MI and WI than there was in MI. All other weather related variables were excluded from the final model.

Similar to the PHDI model set, temperature had larger effects on productivity rates than did precipitation. In this reduced time series data set, the most influential predictor variable was the POND variable for Minnesota. Both Michigan
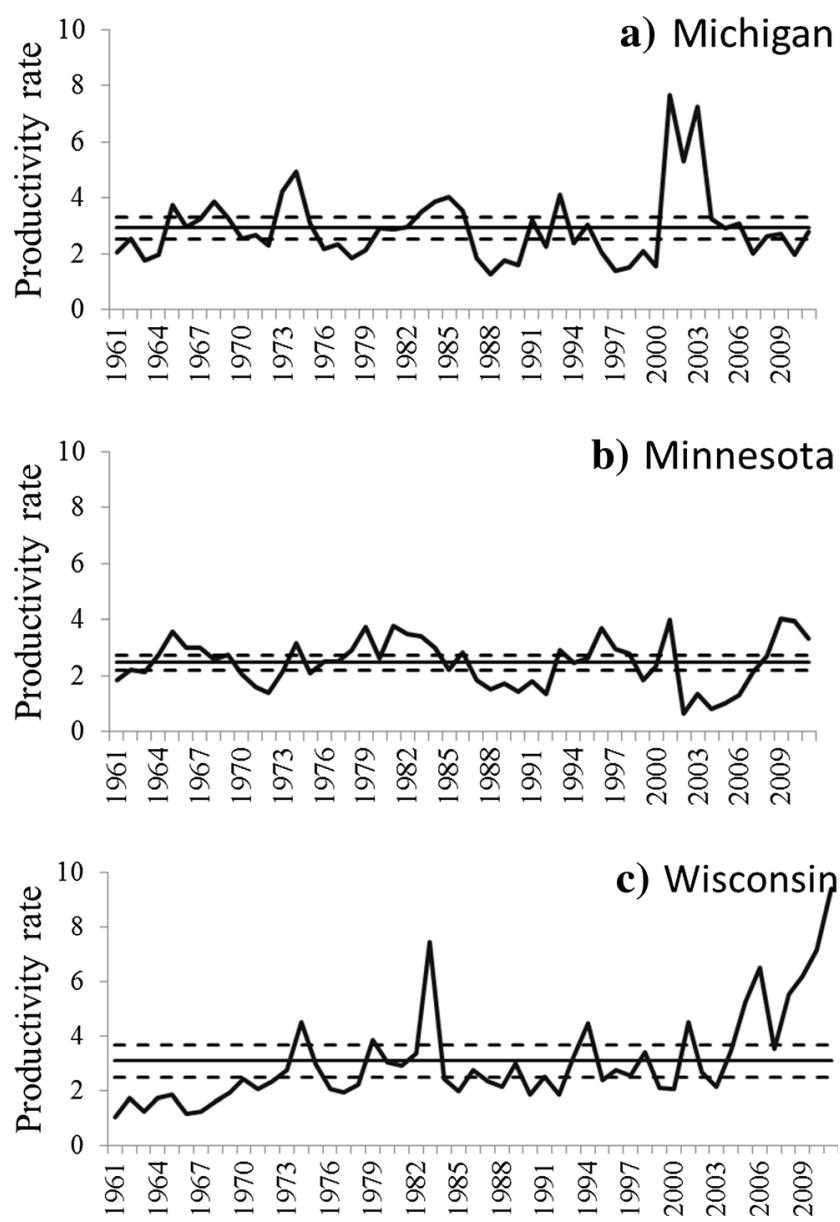

Fig. 2 Annual productivity rates for mallards in the 3 GLS: a Michigan; b Minnesota; and c Wisconsin with long-term average (solid horizontal line) and $95 \% \mathrm{CI}$ (dashed horizontal lines) 
Table 1 Pearson correlation coefficients (r) between Michigan, Minnesota and Wisconsin productivity rates, 1961-2011, excluding 2001, 2003 and 2011 due to extreme outliers

\begin{tabular}{lll}
\hline Variable & MN & WI \\
\hline MI & $0.01 \mathrm{NS}$ & $0.10 \mathrm{NS}$ \\
$\mathrm{MN}$ & & $0.25^{*}$ \\
\hline
\end{tabular}

${ }^{*} P<0.1$ and NS $=$ nonsignificant value, $P>0.4$

and Minnesota had lower productivity than Wisconsin. The effect of MALL (population density) was not evident in any model within AICc of 4 from the top model. Furthermore, post hoc analyses examining the relation between LincolnPetersen estimates of adult females and productivity rates suggest evidence of density dependence on productivity in Michigan and Wisconsin (Fig. 5). Although the estimates of female abundance and productivity are not independent, there appears to be a nonlinear relation and a point where productivity rates may not decrease given an increase in female mallard abundance.

\section{Discussion}

Our results suggest that annual variation in GLS mallard productivity rates was most influenced by wetland hydrologic conditions, as indexed by both the PHDI and POND variables, more so than temperature, precipitation, and overall mallard abundance during the breeding season. Hydrology is an important component of wetlands that likely reflects habitat availability and quality for mallards during settling, nesting, and the brood rearing phase. Mallard nest survival in the aspen parklands has been linked to the amount of herbaceous vegetation on study areas and total precipitation for the 12 months prior to nesting; also, nesting effort was positively related to wetland inundation in July and duckling survival was positively related to the proportion of seasonal wetlands holding water in July (Howerter et al. 2014). Others have found similar positive relationships between mallard abundance and pond counts which might result from more birds settling to breed or greater return of birds breeding or produced in previous years when landscapes are wet (Stoudt 1969; Krapu et al. 1983; Kaminski and Prince 1984; Leitch and Kaminski 1985; Johnson and Grier 1988). Our results for the POND data set corroborate these finding in that the estimate of ponds for Minnesota in the POND model set explained more variation than any of the other predictor variables in both model sets, supporting our hypothesis that under wetter conditions (more available habitat) productivity rates would increase. We caution though that western Minnesota is considered the PPR ecoregion and vital rates of mallards are likely to be different than those breeding further east in the Prairie Hardwood and Boreal Hardwood ecoregions (Coluccy et al. 2008; Howerter 2014). Furthermore in the PONDS data set, Minnesota had a larger sample size of the PONDS variable than did Michigan and Wisconsin ( $n=44$ vs $n=39$ and $n=20$ years respectively) and effect of PONDS was much stronger in Minnesota than the other two states. While this traditional measure of breeding habitat availability may be a reliable predictor for productivity in the PPR, it may not be as reliable for the GLS as these data potentially do not classify wetlands as potential breeding habitat (i.e. sheet water in fields) and this variable may too coarsely index changes in hydrology to be a useful predictor of breeding habitat availability. Many wetlands of the GLS are permanent or semi-permanent lakes, ponds, and rivers and
Table 2 Backwards model selection results for models (within $\triangle \mathrm{AICc}$ of 4 from the top ranking model) used to explain variation in productivity rates for the PHDI (34 randomly selected years from each state) and POND (1968-2011, 1973-2011, and 1991-2011 for MN, WI, and MI respectively) data sets. The number of model parameters $(\mathrm{K})$ with all models including an intercept, Akaike's information criterion adjusted for small sample size $\left(\mathrm{AIC}_{\mathrm{c}}\right), \mathrm{AIC}_{\mathrm{c}}$ compared with the best model $\left(\Delta \mathrm{AIC}_{\mathrm{c}}\right)$ and deviance, $-2 \times \log$ likelihood of each model

\begin{tabular}{|c|c|c|c|c|}
\hline PHDI model set & $\mathrm{K}$ & $\mathrm{AIC}_{\mathrm{c}}$ & $\Delta \mathrm{AIC}_{\mathrm{c}}$ & Deviance \\
\hline $\mathrm{ST} \_\mathrm{MN}+\mathrm{PHDI}$ & 4 & 310.3 & 0 & 301.9 \\
\hline ST_MN + PHDI + JUNET & 5 & 310.8 & 0.5 & 300.1 \\
\hline ST_MN + PHDI + JUNET +JULYT & 6 & 311.0 & 0.7 & 298.1 \\
\hline PHDI & 3 & 311.3 & 1.0 & 305.1 \\
\hline ST_MN + PHDI + JUNET +JULYT + ST_MI & 7 & 313.3 & 3.0 & 298.1 \\
\hline POND model set & $\mathrm{K}$ & $\mathrm{AIC}_{\mathrm{c}}$ & $\Delta \mathrm{AIC}_{\mathrm{c}}$ & Deviance \\
\hline ST_MI + ST_MN & 4 & 323.2 & 0 & 314.8 \\
\hline${ }^{\mathrm{a}} \mathrm{ST} \_\mathrm{MI}+\mathrm{ST} \_\mathrm{MN}+\mathrm{P}+\mathrm{ST} \_\mathrm{MN} * \mathrm{P}$ & 6 & 324.1 & 0.9 & 311.2 \\
\hline${ }^{\mathrm{a}} \mathrm{ST}$ _MI + ST_MN + P + JULYT + ST_MN*P & 7 & 324.1 & 0.9 & 308.9 \\
\hline $\begin{array}{l}\text { aST_MI + ST_MN + P + JUNET + JULYT + } \\
\text { ST_MN*P }\end{array}$ & 8 & 324.3 & 1.1 & 306.8 \\
\hline ST_MI + ST_MN + P & 5 & 325.3 & 2.1 & 314.7 \\
\hline $\begin{array}{l}{ }^{\mathrm{a} S T} \mathrm{ST}+\mathrm{MI}+\mathrm{ST} \_\mathrm{MN}+\mathrm{P}+\mathrm{JUNET}+\mathrm{JULYT}+\mathrm{ST} \mathrm{MN}_{-} * \mathrm{P}+\mathrm{ST}+ \\
\text { MN*JULYT }\end{array}$ & 10 & 325.6 & 2.4 & 305.6 \\
\hline ST_MN & 3 & 326.1 & 2.9 & 319.8 \\
\hline
\end{tabular}

${ }^{a}$ Variables in these models were only used for model-averaging if they were main effects not involved in interactions (i.e. ST_MN and P were not model-averaged in any of these models) 
Fig. 3 Model-averaged parameter estimates $(\beta)$ and model-averaged $95 \% \mathrm{CI}$ from standardized predictor variables across all models for the PHDI model set

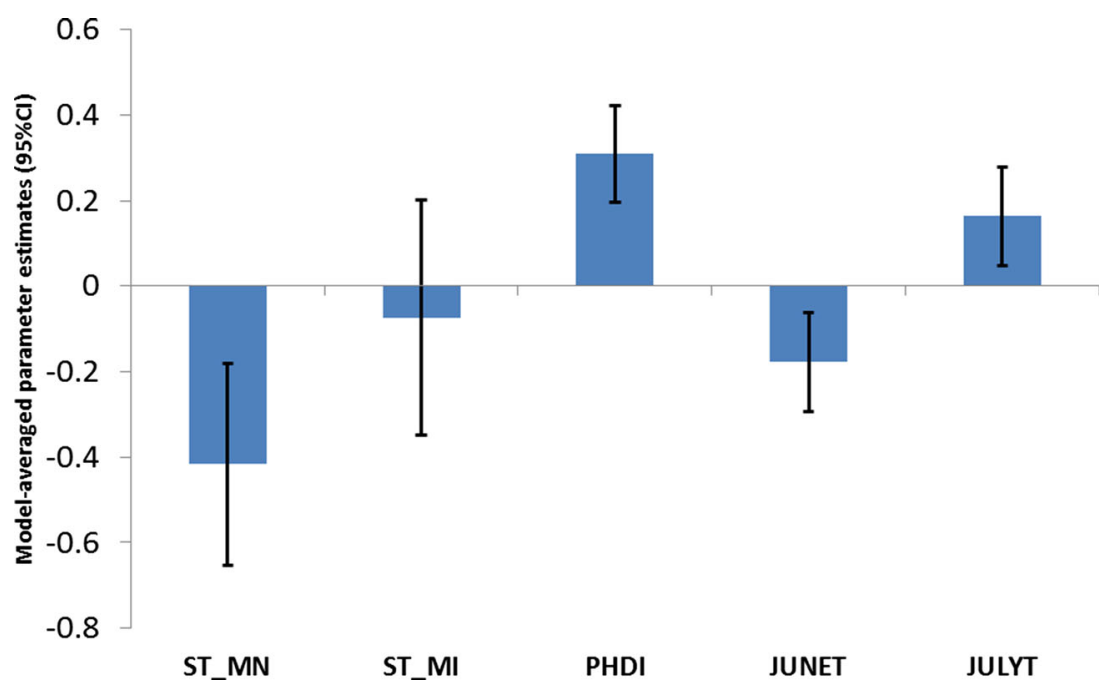

since these typically would not become dry, the count of ponds in the GLS may not capture variation in habitat available for breeding mallards. However, pond counts have varied substantially over the annual spring waterfowl surveys throughout each state (Michigan, Minnesota and Wisconsin pond counts ranged from 375,000-675,000, 175,000-350,000 and 360,000-1.1 million respectively). Furthermore, as noted above, western Minnesota lies primarily within the PPR ecoregion and wetland permanency is likely different than that of the remainder of the GLS. A further analysis excluding western Minnesota would likely be more robust.

Despite large annual change in wetland counts (habitat availability), our metric to test for density dependence (mallard population size at breeding) was not supported in top models. Density dependence in mallards has been linked to the size of breeding populations more so than the extent of breeding habitat availability (Kaminski and Gluesing 1987). Although our final models didn't contain breeding population size, the estimate showed an inverse relation with productivity suggesting slight density dependence. Unfortunately our data set containing breeding population size was restricted to a limited number of years when states flew aerial surveys and didn't include the full time-series. As noted earlier, the coarsescale approach we took to estimating productivity likely influenced our ability to detect density dependence. We feel that density dependence should still be considered a means influencing waterfowl populations at varying spatial scales on key breeding areas.

Cold and wet weather, especially for ducklings $<10$ days old, is expected to negatively affect survival (Mendenhall and Milne 1985; Krapu et al. 2006; Bloom et al. 2012). We did not observe any significant effects of precipitation on productivity rates but we did observe effects of temperature on productivity
Fig. 4 Model-averaged parameter estimates $(\beta)$ and model-averaged $95 \%$ CI from standardized predictor variables across all models for the POND model set

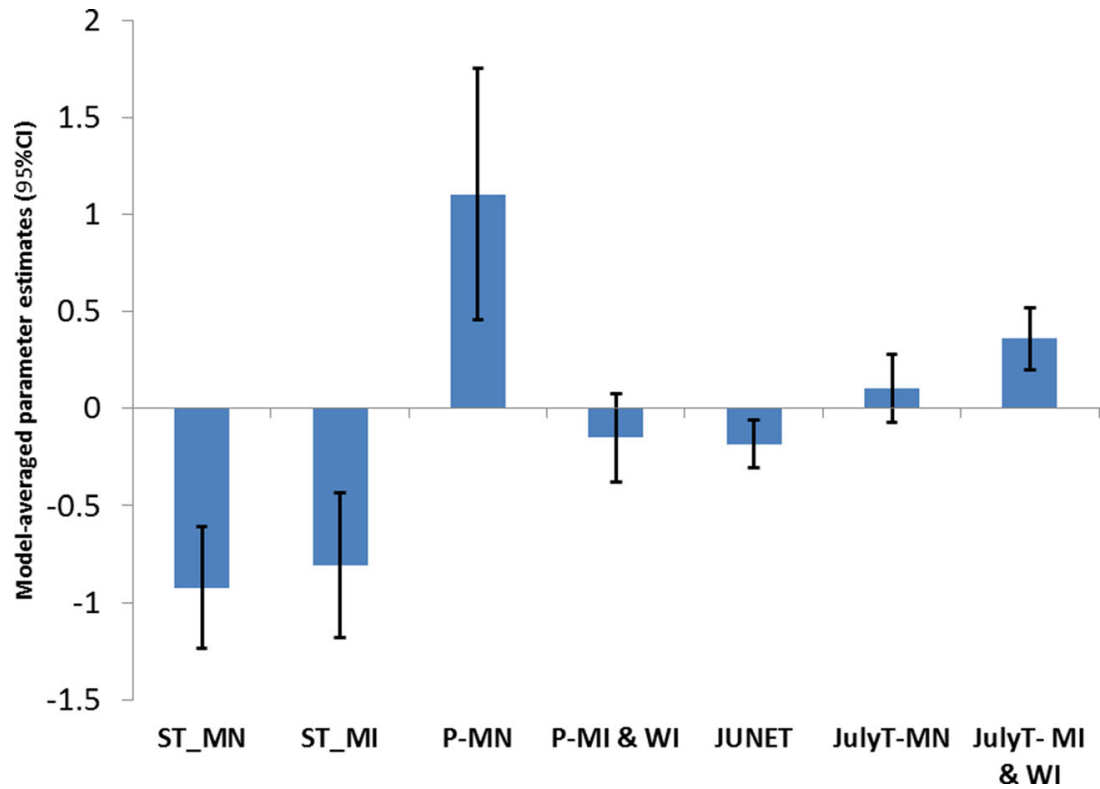



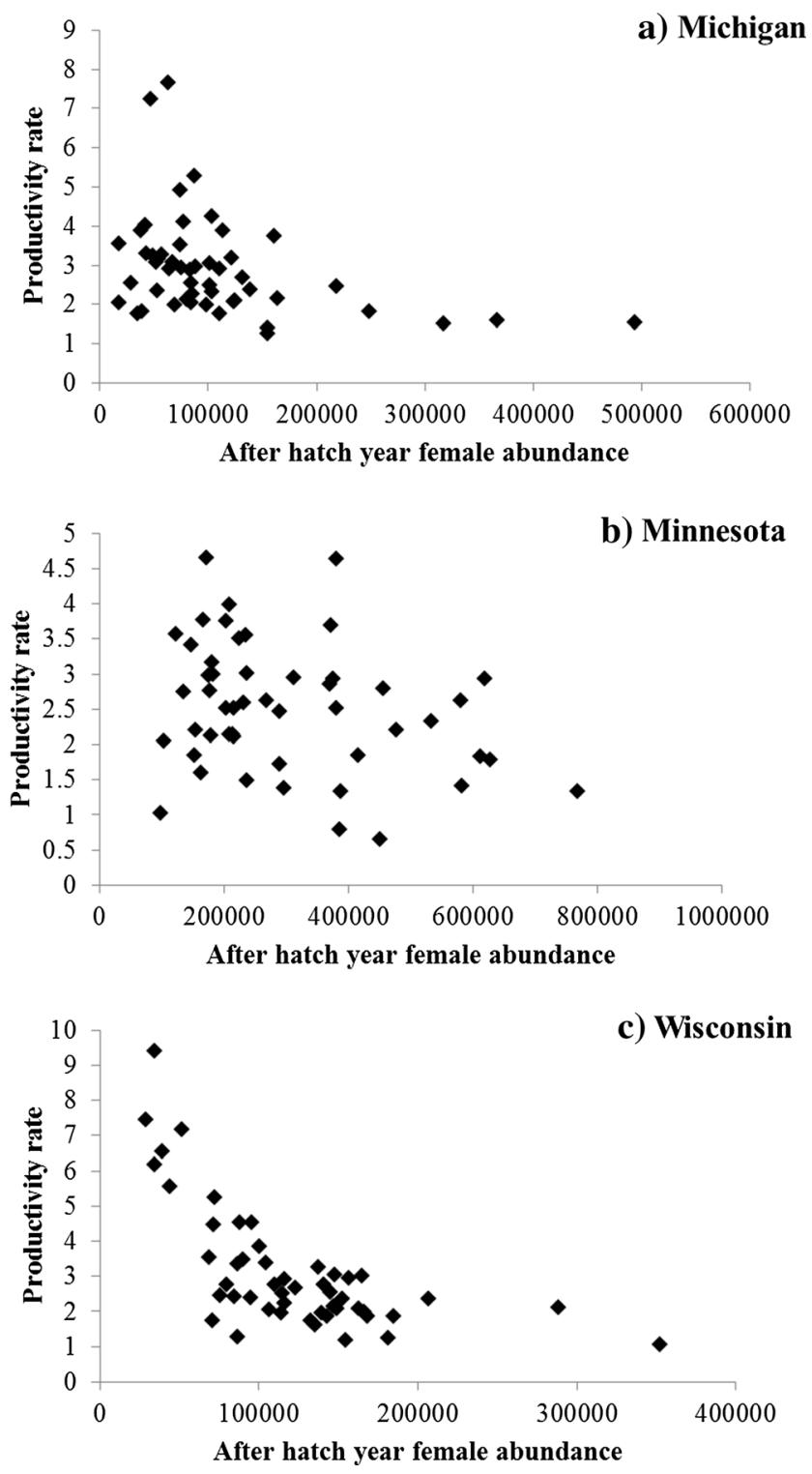

Fig. 5 Relationship between adult female mallard abundance as estimated using Lincoln-Petersen methodology (x-axis) and productivity rate (y-axis) from 1961 to 2011 for a Michigan, b Minnesota and $\mathbf{c}$ Wisconsin rates. Mallard duckling survival in the aspen parklands was negatively related to the number of days in June and July when minimum air temperature dropped below $10{ }^{\circ} \mathrm{C}$ (Howerter et al. 2014). If a brood rearing season was on the average wetter and colder and duckling survival was lower, productivity rates would likely be affected. Extreme temperatures have been shown to influence thermoregulation in oneday-old mallard ducklings (Koskimies and Lahti 1964) and ducklings are more vulnerable to temperature extremes as thermal regulation is incomplete during the first ten days post-hatch (Orthmeyer and Ball 1990; Rotella and Ratti 1992). Furthermore, ducklings can require brooding for up to 3 weeks (Untergasser and Hayward 1973). We studied effects of average monthly temperatures on productivity rates rather than daily extremes. Crissey (1969) found that mallard abundance in a given year was correlated with July pond counts from the previous year and attributed this to increased reproduction. Although July pond counts were not available, we found that July temperature was positively related to productivity rates and a stronger positive effect was noticed in Michigan and Wisconsin than in Minnesota for the PONDS data set. It is possible that monthly averages may be high while daily extremes set record lows and vice versa, thus our methods would fail to capture these extreme events. Furthermore, we estimated productivity at a coarse spatial scale (state boundaries) and there is often a great deal of annual weather variation within states (i.e. individual states) and thus we likely failed to capture varying weather patterns across each state (e.g., climatological regions within states) where duck production may have been higher or lower than a states' average. For example, the Upper Peninsula of Michigan is detached from the Lower Peninsula and weather patterns often very drastically from north to south.

Many factors that might affect mallard productivity changed over the course of the study, but productivity rates remained relatively stable. For example, the amount of Conservation Reserve Program (CRP) acres on the landscape changed the amount of upland herbaceous cover in the GLS during the mid-1980's (Fig. 6). Also, invasive wetland plant species such
Fig. 6 Acreage of land in the GLS that was enrolled in the CRP program from 1986 to 2013

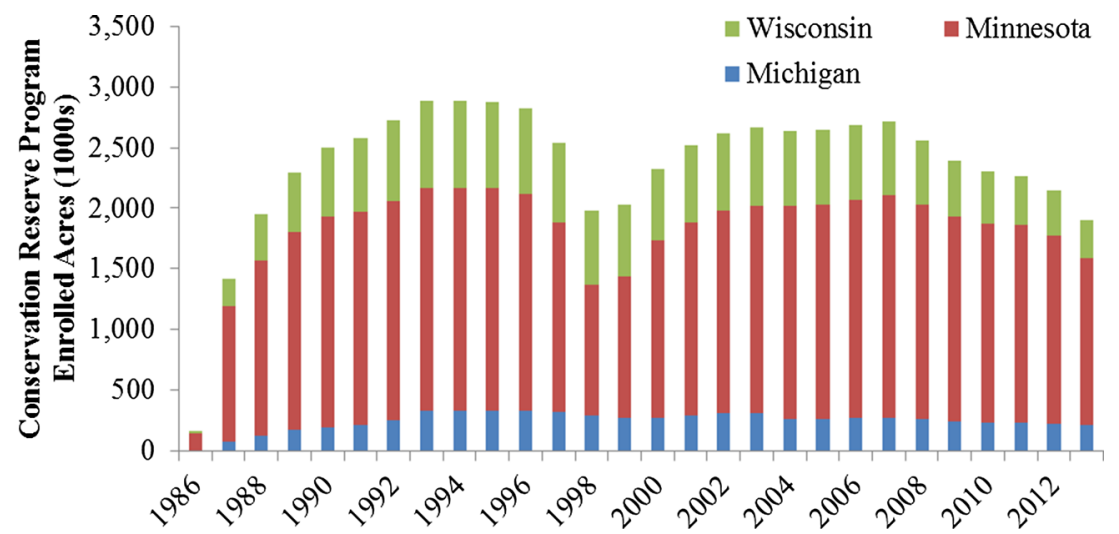


as purple loosestrife and phragmites became established. Furthermore, total wetland acreage throughout Michigan's Southern Lower peninsula has declined over the past thirty years, potentially leading to less breeding habitat for waterfowl and other water birds (Ducks Unlimited 2005). While some studies suggest that the decline of the GLS mallard breeding populations could be linked to a decline in productivity (Van Horn et al. 2006), our results suggest that long-term productivity rates have remained relatively stable, or increased in the case of Wisconsin, despite considerable annual variation. Productivity rates were significantly different between Minnesota and Wisconsin in the PHDI data set. We suspect this is due to differences in ecoregions amongst portions of the GLS. Portions of Minnesota that are ideal for breeding waterfowl and hold a significant portion of the breeding population, lie within the PPR and past research has demonstrated differences among effects of climate in the ecoregions (Soulliere et al. 2007; Coluccy et al. 2008). Furthermore, variation in vital rates effecting population growth rates are different for mallards breeding in geographically diverse breeding regions (Coluccy et al. 2008; Howerter et al. 2014).

Coluccy et al. (2008) found that breeding season parameters such as nest success and duckling survival account for $63 \%$ of the variation in annual population growth rate. Our results suggest July temperature and breeding habitat availability effect productivity rates and this is likely due to increased nest success and duckling survival when breeding habitat is abundant and July is on average warmer. Contrasting results were observed with average June temperatures by showing a negative relationship with productivity. June is likely the month that the majority of mallard nests hatch (Bellrose 1976) and predation rates on nests decline as the breeding season progresses (Greenwood et al. 1995). Furthermore, natural disasters have been found to have minimal effects on nest loss in riparian bird communities (Best and Stauffer 1980).

The importance of breeding habitat to successful waterfowl reproduction and abundance is well documented. Furthermore, annual variation in breeding habitat availability is likely greater in the PPR than the Prairie and Boreal Hardwood transition ecoregions (Kantrud et al. 1989; Soulliere et al. 2007), suggesting that mallard breeding abundance and possibly productivity likely vary more on an annual basis in the PPR ecoregion than it does in the GLS. Variation in water levels across the GLS has been linked to climatic change at multiple scales (Keough et al. 1999). Recent climate change models predict areas of the upper Midwest are likely to experience dryer and hotter summers (Hayhoe et al. 2009), which could lead to poorer quality habitat through decreased water depth and consequently altered emergent vegetation patterns (Cowardin et al. 1988; Simpson et al. 2007) thus limiting resources for the breeding season potentially leading to decreased breeding populations of mallards (Sorensen et al. 1998).
Our productivity rate estimates were higher than biologically likely for some years (i.e. productivity rates $>8$ young/ adult hen). Mallards typically lay a clutch of $\sim 9$ eggs (Bellrose 1976) and it would be unlikely for all eggs to survive until fledging. These extreme estimates in productivity rates might be linked to: 1) an early influx of migrating mallards with added harvest from other breeding locales, 2) a larger than normal sample of harvested mallards from a certain area (i.e. banding just prior to opening of hunting seasons on a managed waterfowl area) or 3) biased samples of waterfowl harvest reported from hunters (Wright 1978). Nonetheless, most of our estimates are consistent and provide a means to conduct long-term studies (Gibbs et al. 1999) to understand variation in reproductive rates as often times there is a great deal of annual variation and trends correlating with climatic events.

This research suggests that although productivity rates have been stable over the past 50 years, long-term climatic change could influence future productivity of mallards in the GLS through decreased quantity and quality of breeding and brood rearing habitat availability. We also found that there appears to be some non-linear density dependence effects acting upon reproduction by using a Lincoln-Petersen estimate of female mallard abundance. Furthermore, these models could be used in combination with future climate models predicting PHDI values and thus help managers make decisions on sustainable population level goals for mallards given climatic variation.

Acknowledgments Funding for this project was provided by the Michigan Department of Natural Resources through the PittmanRobertson research grant and Michigan State University. This funding supported a graduate student to carry out this research project. Also, we would like to acknowledge Robert Rafthovich and Kristi Wilkins from the United States Fish and Wildlife Service harvest branch Division for helping fulfill our many data requests and answering the many questions we had regarding the use of harvest data that would be applicable to our project.

Open Access This article is distributed under the terms of the Creative Commons Attribution 4.0 International License (http:// creativecommons.org/licenses/by/4.0/), which permits unrestricted use, distribution, and reproduction in any medium, provided you give appropriate credit to the original author(s) and the source, provide a link to the Creative Commons license, and indicate if changes were made.

\section{References}

Anteau MJ (2012) Do interactions of land use and climate affect productivity of waterbirds and prairie-pothole wetlands? Wetlands 32:1-9

Batt BD, Anderson MG, Anderson CD, Caswell FD (1989) The use of prairie potholes by North American ducks. In: van der Valk AG (ed) Northern prairie wetlands. Iowa State University Press, Ames, pp. 204-227

Bellrose FC (1976) Ducks, geese, and swans of North America. Stackpole Books, Harrisburg

Best LB, Stauffer DF (1980) Factors affecting nesting success in riparian bird communities. Condor 82:149-158 
Bethke RW, Nudds TD (1995) Effects of climate change and land use on Canadian prairie-parklands. Ecol Appl 5:588-600

Bloom PM, Clark RG, Howerter DW, Armstrong LM (2012) Landscapelevel correlates of mallard duckling survival: implications for conservation programs. J Wildl Manag 76:813-823

Boyd H (1981) A fair future for prairie ducks: cloudy further north. Trans North Am Wildl Nat Resour Conf 46:85-93

Boyd H (1985) The large-scale implications of agriculture on ducks in the prairie provinces, 1956-81. Canadian Wildlife Service 149

Burnham KP, Anderson DR (2002) Model selection and multimodel inference: A practical information-theoretic approach, 2nd edn. Springer, New York

Coluccy JM, Yerkes T, Simpson R, Simpson JW, Armstrong L, Davis J (2008) Population dynamics of breeding mallards in the great Lake states. J Wildl Manag 72:1181-1187

Cowardin LM, Johnson DH, Shaffer TL, Sparling DW (1988) Applications of a simulation model to decisions in mallard management. U. S. Fish and Wildlife Service Technical Report 17, Washington, DC

Cox RC Jr, Hanson MA, Roy CC, Euliss NH Jr, Johnson DH, Butler MG (1998) Mallard duckling growth and survival in relation to aquatic invertebrates. J Wildl Manag 62:124-133

Crissey WF (1969) Prairie potholes from a continental viewpoint. Saskatoon wetlands seminar, Canadian Wildlife Service Report

Dahl TE (2011) Status and trends of wetlands in the conterminous United States 2004-2009. U.S. Department of the Interior, Fish and Wildlife Service, Washington D. C.

Dahl TE, Allord GJ (1996) History of wetlands in the conterminous United States. In: Fretwell JD, Wlliams JS, Redman PJ (eds.) National Water Summary on Wetland Resources. United States Geological Survey Water-Supply Paper 2425:19-26

Ducks Unlimited (2005) Updating the National wetland inventory (NWI) for the southern lower peninsula of Michigan. Final report submitted to the. U.S. Fish and Wildlife Service Great Lakes Coastal program office, Ducks Unlimited Great Lakes/Atlantic Regional Office, Ann Arbor, Michigan http://www.ducks.org/media.Conservation/GLARO/_ documents/_library/gis/NWI-FinalReport.pdf

Euliss NH Jr, LaBaugh JW, Fredrickson LH, Mushet DM, Laubhan MK, Swanson GA, Winter TC, Rosenberry DO, Nelson RD (2004) The wetland continuum: a conceptual framework for interpreting biological studies. Wetlands 24:448-458

Gibbs JP, Snell HL, Causton CE (1999) Effective monitoring for adaptive wildlife management: lessons from the Galapagos Islands. J Wildl Manag 63:1055-1065

Glick P (2005) The waterfowler's guide to global warming. National Wildlife Federation, Washington, DC

Greenwood RJ, Sargeant AB, Johnson DH, Cowardin LM, Shaffer TL (1995) Factors associated with duck nest success in the prairie pothole region of Canada. Wildl Monogr 128:1-57

Grueber CE, Nakagawa S, Laws RJ, Jamieson IG (2011) Multimodel inference in ecology and evolution: challenges and solutions. J Evol Biol 24:699-711

Hayhoe K, VanDorn J, Naik V, Wuebbles D (2009) Climate change in the Midwest. In: Confronting climate change in the U.S. Midwest. Union of concerned scientists. Available online: http://ucsusa. org/assets/documents/global_warming/midwest-climate-impacts. pdf — accessed 1/9/2014

Heitmeyer ME, Fredrickson LH (1981) Do wetland conditions in the Mississippi delta hardwoods influence mallard recruitment? Transaction of North American Wildlife and Natural Resources Conference 46:44-57

Henny CJ, Blus LJ, Hoffman DJ, Sileo L, Audet DJ, Snyder MR (2000) Field evaluation of lead effects on Canada geese and mallards in the Coeur d'Alene River basin, Idaho. Arch Environ Contam Toxicol 39(97): 112

Hoegh-Guldberg O, Bruno JF (2010) The impact of climate change on the world's marine ecosystems. Science 328:1523-1528
Hoekman ST, Gabor TS, Maher R, Murkin HR, Armstrong LM (2004) Factors affecting survival of mallard ducklings in southern Ontario. Condor 106:485-495

Howerter DW, Anderson MG, Devries JH, Joynt BL, Armstrong LM, Emery RB, Arnold TW (2014) Variation in mallard vital rates in Canadian aspen parklands: the prairie habitat joint venture assessment. Wildl Monogr 188:1-37

Jessen RL (1970) Mallard population trends and hunting losses in Minnesota. J Wildl Manag 34:93-105

Johnson DH, Grier JW (1988) Determinants of breeding distributions of ducks. Wildl Monogr 100:1-37

Johnson DH, Shaffer TL (1987) Are mallard declining in North America? Wildl Soc Bull 15:340-345

Johnson WC, Boettcher SE, Poiani KA, Guntenspergen GR (2004) Influence of weather regimes on the water levels of glaciated prairie wetlands. Wetlands 24:385-398

Johnson WC, Millett BV, Gilmanov T, Voldseth RA, Guntenspergen GR, Naugle DE (2005) Vulnerability of northen prairie wetlands to climate change. Bioscience 55:863-872

Kaminski RM, Gluesing EA (1987) Density- and habitat-related recruitment in mallards. J Wildl Manag 51:141-148

Kaminski RM, Prince HH (1984) Dabbling duck-habitat associations during spring in Delta marsh, Manitoba. J Wildl Manag 48:37-50

Kantrud HA, Krapu GL, Swanson GA (1989) Prairie basin wetlands of the Dakotas: a community profile. U.S. Fish and Wildlife Service Biological Report 85

Keough JR, Thompson TA, Guntenspergen GR, Wilcox DA (1999) Hydrogeomorphic factors and ecosystem responses in coastal wetlands of the Great Lakes. Wetlands 19:821-834

Korschgen CE, Kenow KP, Green WL, Johnson DH, Samuel MD, Sileo L (1996) Survival of radio-marked canvasback ducklings in northwestern Minnesota. J Wildl Manag 60:120-132

Koskimies J, Lahti L (1964) Cold-hardiness of the newly hatched young in relation to the ecology and distribution in ten species of European ducks. Auk 81:281-307

Krapu GL (1974) Avian mortality from collisions with overhead wires in North Dakota. Prairie Naturalist 6:1-6

Krapu GL, Reinecke KJ (1992) Foraging ecology and nutrition. In: Batt BD, Afton AD, Anderson MG, Ankney CD, Johnson DH, Kadlec JA, Krapu GL (eds.) Ecology and management of breeding waterfowl University of Minnesota Press, Minneapolis pp 1-29

Krapu GL, Klett AT, Jorde DG (1983) The effect of variable spring water conditions on mallard reproduction. Auk 100:689-698

Krapu GL, Greenwood RJ, Dwyer CP, Kraft KM, Cowardin LM (1997) Wetland use, settling patterns and recruitment in mallards. J Wildl Manag 61:736-746

Krapu GL, Pietz PJ, Brandt DA, Cox RR Jr (2000) Factors limiting mallard brood survival in prairie pothole landscapes. J Wildl Manag 64:553-561

Krapu GL, Pietz PJ, Brandt DA, Cox RR Jr (2006) Mallard brood movements, wetland use, and duckling survival during and following a prairie drought. J Wildl Manag 70:1436-1444

Krementz DG, Asante K, Naylor LW (2013) Autumn migration of Mississippi flyway mallards as determined by satellite telemetry. J Fish Wildlife Manag 2:238-251

Larson DL (1994) Potential effects of anthropogenic greenhouse gases on avian habitats and populations in the northern Great Plains. Am Midl Nat 131:330-346

Leitch WG, Kaminski RM (1985) Long-term wetland-waterfowl trends in Saskatchewan grasslands. J Wildl Manag 49:212-222

Lincoln FA (1930) Calculating waterfowl abundance on the basis of banding returns. U.S. Department of Agriculture Circular No. 118

March JR, Hunt RA (1978) Mallard population and harvest dynamics in Wisconsin. Wisconsin Department of Natural Resources. Technical bulletin 
McCarty JP (2001) Ecological consequences of recent climate change. Conserv Biol 15:320-331

Mendenhall VM, Milne H (1985) Factors affecting duckling survival of eiders Somateria mollissima in Northeast Scotland. Ibis $127: 148-158$

NABCI (2000) North American bird conservation initiative: bird conservation region descriptions. Map and supplement. U.S. Fish and Wildlife Service, Division of Bird Habitat Conservation, Arlington, VA

NCDC (2012) Time bias corrected divisional temperature, precipitation, and drought index. Available online: http://www.ncdc.noaa. gov/temp-and-precip/—accessed: 6/15/2013

Nichols JD, Blohm RJ, Reynolds RE, Trost RE, Hines JE, Bladen JP (1991) Band reporting rates for mallards with reward bands of different dollar values. J Wildl Manag 55:119-126

Orthmeyer DL, Ball JJ (1990) Survival of mallard broods in Benton Lake National Wildlife Refuge in northcentral Montana. J Wildl Manag 54:62-66

Parker IM, Simberloff D, Londsdale WM, Goodell K, Wonham M, Kareiva PM, Williamson MH, Von Holle B, Moyle PB, Byers JE, Goldwasser L (1999) Impact: toward a framework for understanding the ecological effects of invaders. Biol Invasions 1:3-19

Peterson SA, Carpenter L, Guntenspergen G, Cowardin LM (1997) Pilot test of wetland condition indicators in the prairie pothole region of the United States. US Environmental Protection Agency, Office of Research and Development, Washington, D.C. USA

Pietz PJ, Krapu GL, Brandt DA, Cox RR (2003) Factors affecting gadwall brood and duckling survival in prairie pothole landscapes. J Wildl Manag 67(3):564

Prince HH, Padding PI, Knapton RW (1992) Waterfowl use of the Laurentian Great Lakes. J Great Lakes Res 18:673-699

Reynolds RE (1987) Breeding duck population, production and habitat surveys, 1979-85. North American wildlife and natural resources conference. Transactions 52:186-205

Ringleman JK (1992) Identifying the factors that limit duck production. United States Fish Wildlife Leaflet 13.2(7):1-8

Rotella JJ, Ratti JT (1992) Mallard brood survival and wetland habitat conditions in South-Western Manitoba. J Wildl Manag 54:499-507

SAS Institute Inc (2004) SAS 9.3. SAS Institute Inc, Cary, NC

Scott RW, Huff FA (1996) Impacts of the great lakes on regional climate conditions. J Great Lakes Res 22:845-863

Sedinger JS (1992) Ecology of prefledging waterfowl. In: Batt BD, Afton AD, Anderson MG, Ankney CD, Johnson DH, Kadlec JA, Krapu GL (eds.) Ecology and Management of Breeding Waterfowl University of Minnesota Press, Minneapolis pp 109-127

Simpson JW, Yerkes TJ, Smith BD, Nudds TD (2005) Mallard duckling survival in the Great Lakes region. Condor 107:898-909
Simpson JW, Yerkes TJ, Nudds TD, Smith BD (2007) Effects of habitat on mallard duckling survival in the Great Lakes region. J Wildl Manag 71:1885-1891

Snell EA (1987) Wetland distribution and conversion in southern Ontario. Inland waters and Lands Directorate, Environment Canada, Ottawa, ON, Canada Table 6. Working paper 48, En 73-4/48E

Sorensen LG, Goldberg R, Root TL, Anderson MG (1998) Potential effects of global warming on waterfowl populations breeding in the northern Great Plains. Clim Chang 40:343-369

Soulliere GJ, Potter BA, Coluccy JM, Gatti RC, Roy CL, Luukkonen DR, Brown PW, Eichholz MW (2007) Upper Mississippi river and great lakes region joint venture waterfowl habitat conservation strategy. U.S. Fish and Wildlife Service, Fort Snelling, Minnesota

Stoudt JH (1969) Relationships between waterfowl and water areas on the Redvers Waterfowl Study Area. In: Saskatoon Wetland Seminar Canadian Wildlife Service Report Series 6 Ottawa pp 123-131

Talent LG, Jarvis RL, Krapu GL (1983) Survival of mallard broods in south-Central North Dakota. Condor 85:74-78

Thompson DQ, Stuckey RL, Thompson EB (1987) Spread, impact, and control of purple loosestrife (Lythum salicaria) in North American wetlands. U. S. Fish and Wildlife Service. 55 pages. Jamestown, ND: Northern Prairie Wildlife Research Center online. http://npwrc. usgs.gov/resource/plants/loostrf/index.htm (Version 04JUN99)

U. S. Fish and Wildlife Service (2013) Trends in duck breeding populations, 1955-2013. U. S. Department of the Interior, Washington, D. C. USA

U. S. Fish and Wildlife Service (2014) Adaptive harvest management: 2014 Hunting season. U. S. Department of the Interior, Washington, D. C. 62 pp. Available online at http//www.fws. gov/migratorybirds/mgmt/AHM/AHM-intro.htm

Van Horn K, Benton K, Gatti R (2006) Waterfowl breeding population survey for Wisconsin, 1973-2006. Wisconsin Department of Natural Resources. Wildlife Management Administrative Report, Madison, WI

Weller MW, Spatcher CS (1965) Role of habitat in the distribution and abundance of marsh birds. Iowa Agricultural and Home Economics Experiment Station Special Report 43

Welling CH, Becker RL (1993) Reduction of purple loosestrife establishment in Minnesota wetlands. Wildl Soc Bull 21:56-64

Wright VL (1978) Causes and effects of biases on waterfowl harvest estimates. J Wildl Manag 42:251-262

Zimmerman GS, Link WA, Conroy MJ, Sauer JR, Richkus KD, Boomer GS (2010) Estimating migratory game-bird productivity by integrating age ratio and banding data. Wildl Res 37:612-622

Zuwerink DA (2001) Changes in the derivation of mallard harvests from the northern US and Canada, 1966-1998. Ohio State University, Thesis 